\title{
Urban and Regional Horizons
}

\author{
Edited by GORDON MACLEOD
}

\section{Conceptual Vectors of African Urbanism: 'Engaged Theory-Making' and 'Platforms of Engagement'}

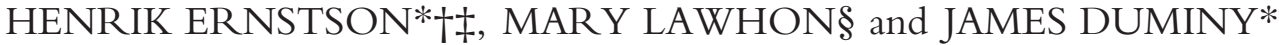 \\ *African Centre for Cities, University of Cape Town, Upper Campus, Pvt Bag X3, Rondebosch (Cape Town) 7701, South \\ Africa.Emails: henrik.ernstson@uct.ac.za and jwa.duminy@uct.ac.za \\ †Department of History, Stanford University, Stanford, CA, USA. Email: henrik.ernstson@stanford.edu \\ $\ddagger$ KTH Environmental Humanities Laboratory, Division of History of Science, Technology and Environment, KTH Royal Institute \\ of Technology, Stockholm, Sweden \\ $\S$ Department of Geography, Geoinformatics and Meteorology, University of Pretoria, Private Bag X20, Hatfield (Pretoria) 0028, \\ South Africa.Email: mary.lawhon@up.ac.za
}

(Received May 2013: in revised form January 2014)

ERnstson H., LAwHON M. and Duminy J. Conceptual vectors of African urbanism: 'engaged theory-making' and 'platforms of engagement', Regional Studies. With increasing urbanization in the global South, and Africa in particular, scholars have called attention to the limited explanatory capacity of existing theory. Ananya Roy suggests developing conceptual vectors based on regional histories and contexts. Two such vectors with relevance beyond Africa are identified and developed in this paper. The developmentalist focus of African urban work provides insights into challenges of linking academic theory with progressive changes in practice, what is called here 'engaged theory-making'; and conditions of informality enable 'platforms of engagement' - particular modes of organizing towards radical incremental change. The strengths of African research are highlighted, critical questions are raised and further work is encouraged.

Comparative urbanism Africa Urban theory Practice Conceptual vectors Informality

ERNSTSON H., LAWHON M. and DUMINY J. 非洲城市主义的概念向量：“参与的理论建构”与“参与平台”，区域研究。随着 全球南方的日益城市化, 特别是非洲地区, 学者们已开始呼吁关注既有理论解释能力的局限性。罗伊（Ananya Roy） 建议根据区域的历史及脉络来发展概念向量, 本文便将指认并建构此般超越非洲关联性的两个向量。发展主义对于非 洲城市的关注，为连结学术理论与实际的激进变革之挑战提供了洞见，在此称之为 ‘参与的理论建构’; 而非正式性的 状态, 则使得 ‘参与的平台”一亦即有助于达成激进且递增的变革的特别组织模式一成为可能。本文将凸显非洲研究的 长处, 提出批判性的问题, 并促进未来的研究工作。

比较城市主义 非洲 城市理论 实践 概念向量 非正式性

ERnstson H., Lawhon M. et Duminy J. Des vecteurs conceptuels de l'urbanisme africain: la 'construction des théories engagées' et des 'plates-formes d'engagement', Regional Studies. Face à l'urbanisation accrue dans le monde méridionale, et en Afrique en particulier, les savants ont attiré l'attention à la capacité explicative limitée de la théorie actuelle. Ananya Roy suggère la construction de vecteurs conceptuels fondés sur des histoires et des contextes régionaux. Cet article cherche à identifier et à développer deux de ces vecteurs dont la pertinence va au-delà de l'Afrique. L'accent développementaliste mis sur le travail urbain à propos de l'Afrique donne des aperçus du défi de lier la théorie savante aux changements progressifs des pratiques, ce que l'on appelle ici la 'construction des théories engagées'; et les conditions de simplicité permettent des 'plates-formes d'engagement' - des modes d'organisation particuliers sur la voie des changements successifs radicaux. On souligne les points forts de la recherche africaine, il se pose des questions fondamentales et on encourage un approfondissement de la recherche.

Urbanisme comparatif Afrique Théorie urbaine Pratique Vecteurs conceptuels Simplicité 
ERnstson H., Lawhon M. und Duminy J. Konzeptuelle Vektoren des afrikanischen Urbanismus: 'Entwicklung engagierter Theorien' und 'Plattformen des Engagements', Regional Studies. Angesichts der zunehmenden Urbanisierung im weltweiten Süden und insbesondere in Afrika wurde seitens der Wissenschaft auf die begrenzte Erklärungskraft der bisherigen Theorie hingewiesen. Ananya Roy schlägt eine Entwicklung von konzeptuellen Vektoren auf der Grundlage der regionalen Geschichte und Kontexte vor. In diesem Beitrag werden zwei solche Vektoren mit Relevanz über Afrika hinaus identifiziert und weiterentwickelt. Der entwicklungsspezifische Fokus der urbanen Arbeit in Afrika liefert Einblicke in die Herausforderungen bei der Verknüpfung der akademischen Theorie mit den progressiven Veränderungen in der Praxis, was hier als 'Entwicklung engagierter Theorien' bezeichnet wird; die Bedingungen der Informalität ermöglichen 'Plattformen des Engagements' - spezielle Methoden der Organisation hin zu einem radikalen schrittweisen Wandel. Wir verdeutlichen die Stärken der afrikanischen Forschung, stellen kritische Fragen und regen zu weiteren Forschungsarbeiten an.

Vergleichender Urbanismus Afrika Stadttheorie Praxis Konzeptuelle Vektoren Informalität

ERnStSON H., LAwHON M. y Duminy J. Vectores conceptuales del urbanismo africano: ‘elaboración de teorías participativas' y 'plataformas de participación', Regional Studies. Con la creciente urbanización en el hemisferio sur, especialmente en África, los académicos han puesto de relieve la limitada capacidad explicativa de la actual teoría. Ananya Roy sugiere desarrollar vectores conceptuales basados en historias y contextos regionales. En este artículo identificamos y desarrollamos dos de estos vectores con relevancia más allá de África. El enfoque desarrollista sobre el trabajo urbano en África permite apreciar mejor los desafios a la hora de vincular la teoría académica con los cambios progresivos en la práctica, lo que aquí denominamos 'elaboración de teorías participativas', y las condiciones de informalidad permiten la creación de 'plataformas de participación', es decir, métodos especiales de organización hacia un cambio escalonado y radical. Destacamos los puntos fuertes del estudio en África, planteamos cuestiones críticas y recomendamos realizar más estudios al respecto.

Urbanismo comparativo África Teoría urbana Práctica Vectores conceptuales Informalidad

JEL classification: P48

\section{INTRODUCTION}

A growing awareness of the limited relevance of general theory, originating from the global North, to contexts of the global South has resulted in calls for the development of 'theory from the South' (ROBINSON, 2002, 2006; Connell, 2007; Comaroff and Comaroff, 2011). This critique, stemming from a postcolonial perspective, has generally been well received, but enacting these ideas remains a challenge. African scholars continue to seek ways to avoid both the uncritical application of Northern theory and the adoption of theoretical frameworks rooted in African exceptionalism. ROY (2009) provides a framework for negotiating these twin dangers through the notion of conceptual vectors. She posits that the historical context and academic traditions of different world regions has shaped the emergence of particular theoretical developments and trajectories. These conceptual vectors are rooted in particularities that come together in place, and additionally may hold relevance for other contexts. Theory can and should travel outside its original context to be shaped, challenged and reformulated across space. Building on Roy's work, this paper calls attention to research that seeks to develop new theoretical insights rooted in, and relevant to, African cities with broader significance for urban studies. Based on an extensive although non-exhaustive review of the literature, it seeks to articulate conceptual vectors emerging from the particular context and intellectual history of Africa, and to which future work may contribute.
Two theoretical areas are suggested where African urbanists have and continue to develop important insights, namely the conceptual vectors of 'engaged theory-making' and 'platforms of engagement'. On the one hand, academic work of the global North has been critiqued for being detached from practice, and there is an increasing push for this work to become more relevant to practical needs and requirements (IMRIE, 2004). However, the opposite challenge has been levelled at African urban research, which is often seen as excessively developmentalist and too tied up in solving real-world problems (ROBINSON, 2002). So agreeing to this in some extent, it is nonetheless argued here that there is much to learn from an African experience of engaged scholarship and partnership. On the other hand, the combined legacies of colonialism, structural adjustment and the constraints of the global economic system have driven wide-ranging processes of informalization - in production, trading, service provision, land and housing, etc. - in African cities. The search for how radical change towards more just cities is possible in highly informal contexts has created a theoretical discussion around incremental change, highlighting the under-examined capacities of the urban poor for contestation and empowerment.

Our articulation of these vectors is better understood as a humble proposition than an assertion of intellectual territory. Despite repeated claims that there is insufficient research on African cities - from any perspective, on any topic - there remains too much emanating from the continent for all the insights of all authors to 
be taken into account. Further, we have been purposively selective in reviewing the works that are aligned with the conceptual vectors proposed in this paper. This is not to discount work that does not feed into these themes (including a significant body of historical work; cf. COOPER, 1983; FERGUSON, 1992; Coquery-Vidrovitch, 2005), nor to suggest that it is somehow less significant. In light of repeated calls for the development of Southern urban theory, but the still limited success in doing so, the present paper is seen as a moment in which to consolidate the strengths of African work, provide some focus and begin to speak back to established urban theory in a coherent manner.

Before moving on it is important to acknowledge that although this paper seeks to argue about 'African' urban studies and 'African urbanisms', it relies upon a published literature that, for the most part, is written by relatively well-resourced African academics (often based in countries such as South Africa) or authors located outside of Africa, but with an African focus in their work. Most of the authors cited here work on English-speaking African contexts, and are those with connections to global academic circles. This has implications for the question of whether or not it is possible to speak of an 'African' body of urban theory, based on a selective reading of the literature. However, it is maintained that it is often at the interface between Northern and Southern processes and ideas that theoretical innovation is possible. Without disregarding the value of urban work produced by African urbanists and planners, often with extremely limited resources, the urban theoretical innovations reviewed here tend to be those of well-resourced and well-connected locations precisely because in these places there is access to international publications and theoretical debates. This paper focuses on these more audible voices in order to assess some of the current trajectories of urban theoretical innovation in Africa, and in doing so it is acknowledged that many other voices, without the same access to global research and media contexts, will go unheard in the process. Building theory of the South therefore implies an agenda to connect African knowledge networks to wider flows, and to promote the productive clash and meeting of ideas from different parts of the world.

The paper is structured as follows. The next section elaborates on prominent features that have shaped African urban scholarship and the theoretical arguments that underpin the development of conceptual vectors. The third and fourth sections explicate the vectors themselves. The context of, and motivation for, each vector and the associated literature and concepts are identified. It is discussed how research on African cities has traditionally been approached with a functionalist emphasis to solve certain perceived problems with the African city (related to the history of developmentalism on the continent) and through the application of
Northern theory. The paper then describes examples of innovative research and institutions that seek to construct theory with explicit practical significance, or what is called here 'engaged theory'. The fourth section discusses key African urban works that have grappled with how to understand incremental changes that contest broader circuits of power. The paper emphasizes the possibility of new theorizing, moving beyond classic (Northern) theories of collective action and urban social movements, which were based on clear ideas of class and identity and public negotiations. In African urban work the emergence of new social formations in the midst of informalization, which often work under the radar and create communities of practices between residents, civic leaders and civil servants that incrementally change institutional life in the city, can be seen. The paper concludes with reflections on how future research can develop the vectors identified, and the implications for regional urban studies.

\section{WHY DEVELOP AN $A F R I C A N$ URBANISM?}

In the last decade urban studies has increasingly realized the significance of cities in the global South. This comes in part from the growing significance of demographic urban growth, e.g. half of Africa is expected to live in urban areas by 2030 (UN-HABITAT, 2010). However, cities are gaining scholarly attention not just because of their size, but also because there is a growing realization of the limited relevance of mainstream Northern theory to explain city-making and urban cultures developing in the South (RoBINSON, 2002, 2006). Cities in the South are increasingly recognized as having the potential to be key sites for theory-making (ROBINSON, 2002, 2006; ROY, 2009; LAWHON et al., 2014; Sheppard et al., 2013). SEeKings and KeIL (2009, p. vi), for example, call for 'a more thorough-going intellectual "internationalization" of urban studies, in which the goal is to transcend Eurocentric intellectual traditions and practices and help to build an urban scholarship that is as cognizant of global diversity as it is of universalizing processes'. Given this, it is not being argued here that only African cities have something to say on any given subject - but, following MYERS (2011), this paper unapologetically starts with Africanist literature and articulates what it holds, rather than seeking to compare or contextualize within the Northern scholarship. It is argued that there are aspects of urbanization and academic tradition on the continent that ensure that African urban scholars are particularly well placed to conduct certain kinds of theoretical development.

Rejecting the universalism of Northern theory raises uncomfortable spectres of African exceptionalism, and with others (ROBINSON, 2002, 2006, 2011, 2013; Myers, 2011, p. 198; Pieterse, 2010a) this article is situated in the intellectual space between claiming 
African cities are unique (and therefore of little relevance to the rest of the world) and cities as universal (and therefore Northern theory is applicable). The following section provides the theoretical foundation and motivation for both conceptual vectors discussed below. Rather than develop a typology or specify characteristics of African cities, it identifies a confluence of relational processes that weave together to form space (MASsEY, 2005) as well as to utilize a strategic essentialism (as per Spivak; GROSZ and SPIVAK, 1985) to define a category of the 'African city' as a provisional standpoint from where to begin speaking back to established norms of cities. ${ }^{1}$

\section{Challenges to urban theory from African scholarship}

The relationship between African cities and global urban theory has shifted over time (RoBINSON, 2006), and the prospect of speaking back to mainstream theoretical debates is by no means new. Certainly some scholars (King, 1990; Simon, 1992) have already drawn upon neo-Marxist and postmodernist approaches to articulate how African cities fit in and engage with the world economy. And although South African scholars often worked in isolation during the apartheid era, by the end of the 1990s South African geographers were stressing the need for the local discipline to challenge the country's perceived role as a 'special case', and to (re) engage with international disciplinary knowledge (ROGERSON and Robinson, 1999). These calls were linked with a growing criticism of the predominantly applied policy-oriented work arising in relation to post-apartheid imperatives of urban reconstruction and development. Instead, authors such as PARNELL (1997, pp. 891) argued that 'a range of theoretical perspectives usually reserved for consideration of the cities of advanced capitalist societies' could be applied productively to explore the many aspects of 'Third World' urban processes.

In parallel to the South African move towards theoretical extroversion, a powerful postcolonial and poststructuralist African critique of urban theory was also brewing. Critique was shifting from the idea that urbanists could fruitfully apply mainstream theory towards the idea that Northern theories may, at their core, be inadequate to capture the complexity of African urbanization and thereby enable a radically different urban future to be imagined or designed (MBEMBE, 1992; Mbembe and Roitman, 1995). Mabogunje (1990) reviews the application of colonial urban theory to African cities, demonstrating that Africanist scholars have been challenging the relevance of classic Northern theorists for decades. Others emphasized the contemporary limits of Northern theory to African cities (MABIN, 1990). In the field of urban planning, WATSON (2002, 2003) produced a series of articles questioning the relevance of mainstream normative planning theories to the empirical conditions of and praxis in the global South. Mbembe and Nuttall (2004) demanded that African urban studies engage in a theoretical movement beyond the 'twin provinces of anthropology and development studies' as well as 'the analytical and normative strands of functionalist, neoliberal, and Marxist political economy' to once again recognize 'the virtues of curiosity and astonishment at what the (African) world might be' (p. 350; see also Pieterse, 2010a).

Along these lines, Robinson issued a series of challenges for the theorization of African (and other 'Third World') cities beyond the geo-epistemological confines of developmentalism, modernism and 'global city' theory (ROBINSON, 2002, 2006). This call for cosmopolitan analysis of 'ordinary cities' entails a critique of the contextual assumptions, validity claims and utility of general urban theory, and an appeal for the production of African urban work that itself has potential for theoretical generalization. Despite widespread support for these ideas, it remains difficult for Southern scholars to publish articles that are not explicitly situated in relation to established Northern theory (PATEL, 2006). Provincializing Northern authors requires a deep engagement with both Northern theory and Southern contexts, a task many scholars struggle to achieve given the limitations of resources, data availability, language constraints and so on (OldField et al., 2004).

At its most fundamental level, this move represents a will to take African cities seriously in themselves without first relating them to other (EuroAmerican) cities, theoretical constructs, or a developmentalist agenda. For example, MYERs (2011) asks provocatively 'What if the postmetropolis is Lusaka?', reorienting our gaze away from New York, Los Angeles, Paris and Tokyo towards an ordinary African city. He, and others, seek to push the African urbanist's gaze beyond solving urban problems towards accounts of African cities that, amongst other things, emphasize 'intimacy, microscopic social textures, psychic dispositions, aesthetic adventures and agency' (PIETERse, 2011, pp. 1-2). Thus, beyond the statistics that could be assembled around the informal economies of any African city, authors such as SimONE (2004b), Nuttall and Mbembe (2008), and De Boeck and Plissart (2005) sensitize differently, seeking a new base from which to raise questions. In her review of these three books, GUYER (2011, p. 475) notes some commonality in their approach of writing the city with the classic work of Simmel (1903). However, in contrast to Simmel's efforts to generalize urban life, 'these three books evoke the specificity of particular cities'. As Simone (2004b, p. 3) suggests:

[I]n cities where livelihood, mobility, and opportunity seem to be produced and enacted through the very agglomeration of different bodies marked and situated in diverse ways, how can permutations in the intersection 
of their given physical existence, their stories, networks, and inclinations, produce specific value and capacity? If the city is a huge intersection of bodies in need, and with desires in part propelled by the sheer number of them, how can larger numbers of bodies sustain themselves by imposing themselves in critical junctures, whether these are discrete spaces, life events, or sites of consumption or production?

To take African cities seriously means to provide texture to the barrage of statistical portraits or structural explanations. Fundamentally, this not only provides a platform from which to rethink urbanization and citymaking more generally - but also critiques how African cities have been represented, written into scholarly texts and made to circulate in the academic literature. Indeed, in sensitizing the reader to new ways of thinking regarding what city-making in Africa is about, these authors strive to interrupt the almost frictionless image of the African city as 'failed', 'hopeless', in 'need of help' or as cities that simply 'don't work'. The use of ethnographic material, of close description loaded with analytical metaphors - intersections, circulations, crossroads (as in SIMONE, 2011b) - is a searching experiment to describe emergent social formations, while finding new constellations of words to make sense, and write the city anew. ${ }^{2}$ Theory-making is threaded closely with fieldwork reporting, and these authors provoke reflection on how to do academic work and put observations into text.

\section{What draws together African cities?}

Roy (2009) proposes that area studies can be used to help globalize urban theory. While critical of the Northern bias of the literature, Roy nonetheless supports the flow of theory - whether from the North or South across space. Importantly, Roy is not bound to a territorial definition of the region but, like AMIN (2004), considers topological regions where the apparent spatial coherence or distinctiveness of 'place' is seen as having emerged through economic, cultural and social relations with other spaces, forged slowly or violently over time (see also MASSEY, 2005; Murdoch, 2006). Knowledge is produced in place, and particular concepts receive more attention in some places. Each region has looked at 'the urban question' differently because of its different intellectual history and social context. For example, Latin American scholarship has been informed by dependency theory, while South Asia's urban studies draw more on postcolonial theory and concepts of the subaltern. While both have placed substantial emphasis on the question of citizenship, these different contexts and intellectual traditions shape the kinds of research and analysis that emerge. In contrast, East Asian studies have paid more attention to economic globalization and cosmopolitanism. Limiting the sites from which theory develops results in missing alternative experiences and the insights these could generate. Roy's argument is not deterministic but instead recognizes the multiplicity of influences converging in places.

Regarding African cities, Roy suggests there are two emerging mandates: 'to understand capitalism in African cities not simply as social relations of production but as forms-in-circulation of racialized bodies, migrant bodies, commodities, superstitions, bribes etc. and to link such forms-in-circulation to African modernities' (Roy, 2009, p. 823). While the present authors agree that these are interesting directions for African scholarship, this is formulated as a single vector, and the implications of this vector are drawn out in more detail as 'platforms of engagement'. This results in a slightly different framing of the contribution and future directions of this vector. Additionally, it is suggested that a wider reading of contemporary and historical African urban literature points towards an additional conceptual vector - 'engaged theory-making'. In proposing these conceptual vectors, the intention is not to suggest that all African urban scholarship does or should contribute to these themes. Instead, it is to point towards what a particular, subjective reading of the literature suggests as two key themes which ought to be further developed.

Before explicating these vectors, we first describe what we - in consultation with other scholars and literature - see as prominent features that shape the production of knowledge in the African context. These four points are not necessarily unique to African cities but have particular salience and influence in shaping African cities and urban scholarship and have led to critical insights into the debates about engaged theorymaking and platforms of engagements. Certainly each of these features plays out in different configurations in each city. These features, it is suggested, have shaped the focus of African urban research, but also the articulation of these features is based on the research that has been undertaken. Thus, there is an iterative relationship between what is seen and what is studied in African (and all) cities.

First, there is a common sense of crisis affecting African cities, in both structural and subjective manifestations (Mbembe and Roitman, 1995; Pieterse, 2008, 2010a; Pieterse and Simone, 2013). Here conditions of violence, informality, poverty and forced mobility tend to undermine urban security, stability and everyday predictability. Occasionally this crisis is portrayed in nightmare scenarios (DAvis, 2006), but for others, crisis could be - although not romantically so - an opportunity for change (PIETERse, 2008; Myers, 2011). Second, a phenomenon that underpins this crisis is a shared experience of colonialism, relatively late decolonization and integration into a particularly peripheral place in the post-colonial world system (Coquery-Vidrovitch, 2005; Freund, 2007). ${ }^{3}$ This results in a degree of commonality in terms of African urban political economy and a limited ability 
for African agency when engaging with global structures. While structural adjustments occurred in other regions, they were particularly difficult to avoid and their impact often felt more deeply in Africa. The downsizing of governments rapidly increased unemployment, even among those with education, and fed an informal economic sector. Structural relations that result in African countries exporting primary goods also means that African cities are urbanizing under different conditions - not in response to demand for urban labour - but despite a general lack of formal urban opportunities (SIMON, 1992; SimONE and Abouhani, 2005; Murray and Myers, 2006; Locatelli and Nugent, 2009; Potts, 2010; Myers, 2011).

Third, whilst recognized as a global phenomenon, informal urban processes have a particularly high degree of visibility and centrality in the shaping of African cityness and urban spatial development (e.g. LourenCO-Lindell, 2004; Simone, 2001, 2004b; Skinner, 2008; Lindell, 2010; Myers, 2011; Kamete, 2013). Taking note of its contested definition and function within planning and urbanization (ROY, 2005, 2011; and see note 4 below), informalization includes the growth of informal settlements, but also the 'informalization of formal settlements' and the rise of 'unregistered social networks in the built environment, livelihood strategies, social reproduction, cultural organization, or political mobilization' (MYERS, 2011, p. 73). Further, it recasts public institutions as loci for informal negotiations and exchanges (PARNELL et al., 2009). ${ }^{4}$

Finally, race, ethnicity and culture remains an undertheorized but important influence (AMIN, 2010). Expressed as 'black urbanism' (SIMONE, 2011a, 2011b) and, relatedly, alternative rationalities (cf. WATSON, 2002, 2003; HARRISON, 2006), work is currently beginning to raise critical questions, if not answers to how these kinds of differences operate in cities. While Northern theory has situated the marginalized as such - marginal to something else, the centre - 'black urbanism' starts theorizing the city among those that were never welcomed to the city, excluded by white rule, colonial rule or middle-class rule (SimONE, 2011b). In spite of not being formally part of 'the city', these outcasts still participated in 'making the city', which can form the basis for urban theory. As such 'black urbanism' is not only an African phenomenon, but also is found in many parts of the world where urban segregation and inequality is a sharp reality, allowing for comparisons of urban experiences that seldom have been put in communication (SimONE, 2011a). Although the meaning and impact of blackness in different contexts remains unclear, issues of segregation, race and class unquestionably shape contemporary African urbanization.

The following two sections develop this paper's arguments for specific conceptual vectors of African urbanism. These particular vectors are drawn from the authors' reading of the literature, the key features identified above, as well as their own experiences and conversations with other African urbanists over the last two years.

\section{ENGAGED THEORY-MAKING}

To do academic work with relevance to both theory and practice remains a critical challenge for scholars everywhere (see the burgeoning research on the concepts of transdisciplinarity and co-production; e.g. Wickson et al., 2006; Mobjork, 2010; Goebel et al., 2010; ANDERSON et al., 2013). Theory is often what is described as taking place at universities, among academics and written about in books and journal articles. There it has traditionally been understood as the contested process whereby general propositions are made and clarified, guiding further research. Practice on the other hand is often portrayed as referring to work with an applied and developmental intention, performed by the state, civil society and development funding agencies to identify and 'solve' a problem.

In taking the regional theory-making of Roy (2009) and Robinson (2002, 2006) seriously, however, a more refined understanding of theory is sought. The aim is to de-centre general propositions and create a space where theoretical propositions from different places can communicate and support a wider array of experiences of urbanization to speak and deflect against each other. Theory-making in this interpretation is thus less about refining propositions towards a general framework and more of a space to debate and develop a set of registers and sensitivities that can move experiences from one context to another, sustaining particularities, while allowing for comparison. ${ }^{5}$

Engaged theory-making, it is suggested, entails working closely with communities, civil servants, politicians, private firms, non-governmental organizations (NGOs) etc. to address real problems, while using these engagements as material for rethinking urbanism, how and why cities operate and function as they do, and how the processes and effects of urbanization can be influenced and changed. To articulate further what is meant by 'engaged theory-making', the paper begins with the long history of developmentalist work in Africa, suggesting that there is potential to reflect on and use this history - problematic as it may be - to understand better links between academia and practice. It is shown that there is a growing body of literature that seeks to build on this history, particularly in the South African context, with the goal to move beyond applying developmentalist academic thinking to practice, and towards the co-production of knowledge with the aim of progressive impacts.

Applied developmental work on African cities has a long history (PARNELL and ROBINSON, 2012; see the review in STREN, 1992, 1994) and has, no doubt, 
made significant contributions to urban practice. The persistent dominance of this work within circulations of knowledge on African cities has however attracted several volleys of critique in recent decades. One element of this critique is that African urban work overwhelmingly concentrates on localized empirical studies that are 'poorly informed theoretically' (MBEmBE and Nuttall, 2004, p. 349), typically underpinned by a functionalist analytical frame, and oriented toward policy recommendations that provide instruments for decision-making, but without exploring alternative conceptual and political possibilities.

However, while the push for more theoretical reflections is implicit in many of the most well-cited African urban works in high-profile journals, there remains a reluctance to step back too far from the issues on the ground, largely due to the sheer scale of the challenges facing many African cities. The debate between Watts (2005) and Nuttall and Mbembe (2005) in Public Culture centres on this basic issue (see also Chipkin, 2005). In essence, while Nuttall and Mbembe reiterate the need to rethink and reimagine the city, Watts pushes the authors to articulate more clearly the practical significance of the descriptive cases. Building on Simone's famous phrase, Watts asks, if 'people are infrastructure' (SimONE, 2004a), what kind of structure is emerging?

In circumstances where economic crisis, urban poverty and environmental health risks are extreme almost to the point of sensory cauterization, with an accompanying paucity of knowledge on these and other issues, generating empirical practice-oriented research can appear the most urgent and ethical option. As Myers (2011, p. 14) notes:

$[T]$ he challenges for African urban studies no longer lie simply or solely with paying more theoretical attention to the marginalized informal, spectral, necropolitan or ordinary settings $[\ldots]$ they lie equally in practice in then attempting to articulate how such urbanization processes might contribute to efforts to improve the quality of life for the inhabitants of these places.

This call signals the particular kind of theory that African urbanists have and continue to articulate. As PARNELL and RoBinson (2012, p. 603) argue, policy and practice have been and remain essential points from which to develop urban theory. While they acknowledge academics' fear of political control of their research topics and findings, they argue that developing theory based on such engagements opens a space for research that is both theoretically rigorous and relevant to those living in and managing the city. Specifically, they suggest that 'overtly practical concerns [... metamorphose] through action-based urban engagement into theoretical reflections'. Their paper suggests that, rather than move directly from empirics to recommendations, it is possible to develop theorizations that improve the intellectual quality of the research and the significance of the findings in practice (see also PARNELL, 2007).

There are several locations on the continent where this blurring of the boundaries between theory, practice and civic engagement is tried out in various forms and levels of commitment, and where the conceptual vector of engaged theory-making could be further elaborated. The Centre for Urban Research and Innovation (CURI, formerly the Urban Innovations Project) at the University of Nairobi, Kenya, has since 2007 developed an arena where scholars, planning authorities, private actors and local organizations representing the urban poor work on collaborative projects and sometimes contested issues, including integration of street vendors and informal markets into 'Nairobi's urban realm' (WANYOIKE, 2013). Other examples include the Lagos Urban Research Network (LURNet), established at the University of Lagos in 2011 as an urban laboratory for theoretical and applied research. Other applied urban research centres have a far longer history, including the Institute of Human Settlement Studies (IHSS) at Ardhi University, Tanzania (founded in 1979); the Centre for Settlement Studies (CSS) at Kwame Nkrumah University of Science and Technology (established in 1959); and in Francophone and Lusophone Africa there are, among others: the Ecole Africaine des Métiers de l'Architecture et de l'Urbanisme (established in 1975) in Togo; the Environnement et Développement Tiers Monde (ENDA-TM) in Senegal, an NGO that has promoted innovative urban practices; and the Centro de Análise de Políticas (CAP) at Universidade Eduardo Mondlane, Mozambique, which also supports urban applied research. Potentially of great importance is the recently established African Urban Research Initiative (AURI), which gathers African (NGO and academic) research centres to develop applied urban research and the co-production of urban knowledge across and at the scale of the continent (DUMiNy, 2013).

Indeed, the notion of extra-academy engagement has long characterized African academic work, and even many theoretically significant works explicitly draw out the practical implications of the research (cf. Simone, 2004b; MCDONAld, 2008; VAN DONK et al., 2008). In South Africa, 'consulting, policy or applied research is a ubiquitous feature of geography departments' (PARnell, 2007, p. 111). OldField et al. (2004) recount how apartheid-era civil society groups sought intellectual support from universities during the 1980s, resulting in long-term cooperation and the co-production of knowledge. The upshot of these academy-civic partnerships, born through 'sustained and critical engagement', was the creation of 'conditions for intellectual creativities in the recipient NGO environment, in community-based organizations (CBOs) and in university contexts' (OLDFIELD et al., 2004, p. 292). 
Among centres as those above, this paper focuses on the African Centre for Cities (ACC), which is well known and constitutes an early indication of how the assemblage of practical-theoretical knowledge on African cities could evolve. 6 The ACC came into being in 2006 based on the decade-long experience from the Urban Problems Research Unit at the University of Cape Town. This unit conducted applied research on a range of urban topics during the 1980s and 1990s, largely from an advocacy perspective, foregrounding the centre's emphasis on external engagement. As a maturing centre, the ACC now functions as a platform for interdisciplinary urban research, gathering 'scientists, engineers, planners and social scientists to work collaboratively on the problem of rethinking the city $[\ldots]$ to produce new knowledge $[\ldots]$ to aid interventions by the state, citizens and their organizations and the private sector' (PARNELL et al., 2009, p. 241). Although the focus is on policy-relevant knowledge, the centre also pushes towards 'novel ways of contemplating and understanding urbanism', often through publications that blur academic, artistic and popular publishing boundaries (e.g. EDJABE and Pieterse, 2010, 2011; Pieterse, 2010b; Pieterse and Simone, 2013; and the biannual magazine CityScapes created by Tau Tavengwa - O'TOOLE et al., 2012).

The centre provides a testing ground for how engaged theory-making can be organized. The ACC CityLabs are dedicated to thematic research areas (such as climate change, urban ecology and healthy cities) in cooperation with the City of Cape Town, based on the interests and challenges faced by the city (PARNELL et al., 2009). Over the course of their operation (the first set of Labs ran for two years), multiple engagements between researchers, government and civil groups helped to develop relationships, social learning and shared expertise, often initiated by concerns within government (ANDERSON et al., 2013). Despite difficulties experiences by all the Labs, real effects were generated: the operations of the Climate Change CityLab, for example, helped to drive a 'shift in how city officials view climate change, taking it from what was previously perceived as exclusively an environmental issue to one of diverse relevance' (ANDERson et al., 2013, p. 6). The ACC seeks to build on these experiences through the development of new methodologies, including embedded research programmes with the City of Cape Town Municipality. As part of the Mistra Urban Futures programme, academic researchers from ACC are placed in local government to work with practitioners to enhance co-learning, while practitioners in government are invited to write-up their knowledge with the assistance of ACC scholars (LAWHON et al., 2012).

The fusing of theory and practice, in historical and contemporary academic work, signals a key conceptual vector from which African urbanists can contribute to the broader field of urban studies. The vector's distinguishing features can be summarized as those of critical reflection, retaining a collaborative yet selfdetermined knowledge production, infused with a devotion to develop strategies of change towards more egalitarian and just forms of city-making. It needs here to be acknowledged that Africanists, along with others, still struggle to develop such strategies of change (salient in the roundtable discussion included in Pieterse (2010b, pp. 241-256, entitled 'Why is transformative change so elusive?'). However, the intention here is to point towards the urgency for building on the developmental history of African cities towards new, more theoretical yet equally engaged approaches to research. The following section will explore some ways in which authors nevertheless have sought to articulate a conceptual basis for a politicaltransformative project, which takes account of the realities of informal urbanization in Africa.

\section{PLATFORMS OF ENGAGEMENT}

How radical change towards more egalitarian forms of urbanization can be made possible has been the subject of extensive debate (e.g. Heynen et al., 2006). This section begins articulating 'platforms of engagement' as a key theoretical contribution to this debate that has emerged through Africanists' work, but with relevance beyond African cities. This conceptual vector builds on empirical studies and theorizations of change in cities with high levels of informality, closely associated with the modalities of contestation and empowerment of the urban poor. Scholars seeking to understand how radical change is possible in contexts that typically lack a traditional revolutionary subject in the form of an urban industrial proletariat have developed a theoretical discussion around incremental change. Such change is made possible through the often unnoticed practices of contestation and empowerment performed by all urban actors, including the urban poor. This theoretical interest is recognized by ROY (2009) and the present paper seeks to elaborate on and expand Roy's review. A conceptual vector is suggested here that focuses not just on describing the empirics, but also on understanding how such joined-up actions can lead towards more substantive change.

African cities and scholarship are suggested as having the potential to describe closely and richly: (1) how interlinked everyday practices of the urban poor form a part in creating the material flows and cultural life of the city; and (2) how these practices intersect, undermine and are complicit with wider circuits of power; which in turn creates (3) a possibility for radical incremental change. To bring out the motivation and context of the vector, it is contrasted with other types of studies that have relied on more traditional theories of collective action and (neo-) Marxist approaches. 


\section{Towards situated theorisations of radical change}

In the 1970s, Marxist explanations including dependency theory emerging from the South American context were applied to Africa (Vengroff, 1977; Bienefeld, 1988; Mabogunje, 1990; Simon, 1992; PotTs, 2010). These were characterized by the analysis of how the oil crisis and structural adjustment programmes imposed from 'outsiders' like The World Bank and the International Monetary Fund (IMF) created a limited ability of Africans to choose their own development paths. This has shifted more recently towards neo-Marxian studies that importantly recognize multiple forms of power, exemplified well by GANDY's (2006) recent study of Lagos (see also FOURCHARD, 2011). Gandy analysed the crisis of Lagos where:

an emerging 'oil culture' has worked powerfully against any civic ethos in public life by fostering widespread opportunism on the part of social and political elites; the illusion of unlimited wealth has served to deflect attention from the efficiency or effectiveness of public services.

(GANDY, 2006, p. 387)

This analytical move recognizes local forms of power, e.g. kinship and cultural norms, but uses the standard categories of elite, civic ethos and public services to make sense and write the analysis.

Although a neo-Marxian approach provides valuable larger-scale structural analysis, it often results in despair over the ubiquity of the problem, its growing intransigence, and the lack of insurgent and collective subjects or organizations in African cities. For example, Gandy fails to find his revolutionary subject in Lagos, and MCDONALD (2008) similarly doubts the likelihood of successful opposition to neoliberalism in Cape Town. Both turn towards revitalizing the state as a solution to their outlined problems. For Gandy, this involves reclaiming the state to reinstall a 'public realm' that can turn mere 'population' to 'citizens' working towards the common good. For McDonald, this may involve Keynesian revisions such as increased public participation, more progressive budgeting, fairer pricing and more service delivery. Or, preferably, it involves more radical restructuring of the economy through means that must be determined through local coalitions. While McDonald argues that the economic conditions are sufficiently oppressive to make Cape Town ripe for change, the prospects for such radical change actually occurring through the rather illusive means suggested are limited.

This lack of finding possibilities for change is one way to understand the move towards situated theorisations from African cities in seeking platforms of engagement. In City Futures, Pieterse (2008, p. 85) writes that 'the challenge is to adopt an approach that recognizes the structuring effect of the economy, bureaucracy and discursive diagrams of power without relinquishing an appreciation of agency'. His critique is twofold: while contending that structuralist or Marxist approaches successfully uncover some mechanisms of power, they tend to oversimplify the play of power and thus can too easily fall into a narrative where the perpetrators and victims of the system are clear. Instead, he argues it is simply inconceivable to approach or move through the city and its futures with irrevocable certainty about what is going on or what is needed to make the place better' (p. 85). He thus emphasizes the need for close ethnographic descriptions without giving up hope of understanding wider circuits of power, as is illustrated below with works from a range of scholars.

\section{Towards understanding wider circuits of power}

Works that seek to describe platforms of engagement generally refrain from outright normative judgment and prescription, in line with postcolonial critiques of modernity and developmentalism (cf. Diouf, 2003; Besteman, 2008). Many authors appear content to sense and script the everyday through ethnographic approaches. However, there is also a move towards linking scales of analysis, to understand how circuits and networks of everyday practices form part of, but also can destabilize, wider circuits of power - be they economic, bureaucratic or cultural. This is a core feature of this conceptual vector and it separates out a smaller number of authors. In a video documentary, DE BOECK (2010) follows the lives attached to a formally closed cemetery in Kinshasa and the many economic transactions tied to this place in getting dead bodies into the ground. But he also shows, and clarifies in his voiceover, how the young in Kinshasa use the death of their friends as an arena to stage their discontent with the ruling elite, and adults and the elderly more generally (see also De Boeck and Plissart, 2005). MBembe (2002) points to the strongly emergent social formations around Christian churches (Pentecostalism) and indigenous Islam, also strongly associated with the urban youth. The interest in describing such platforms of engagements is further theorized by Simone and Pieterse.

Simone provides tools and texts to rethink African cities. Moving with citizens who are less certain of their future, he finds a politics of anticipation, a theoretical register that can 'valorize the many efforts that residents make to use the city' (Simone, 2011b, p. 333) in their everyday life. Although formal organizing efforts figures in his work, his theorizing is broader, including a keen interest in figuring out how the totality of the city is working, in spite, or rather through, vast informality:

In neighbourhoods full of residents struggling to make ends meet on a daily basis, and without effective laws, policies, or institutions capable of imposing functional maps for how people should act with each other, such 
interruptions [between people], such incessant checking and conversations, become the mechanisms for keeping things from getting out of hand.

Working for extensive periods in the cities of his research, Simone generates data by spending time on the streets, forming relationships with tradesmen, households and organized groups: 'six teams of local residents have been documenting various facets of the local social economies in the districts in which they live' (p. 62). Of particular interest is to describe more generalized mechanisms of how economic opportunities are generated, shift and disappear through the many meetings that these cities produce. He tunes his text to describe the many differences that are created in an urban environment - differences in rationalities, imaginaries, economic valuations and prices - and the ability of people to connect these differences:

At the same time, streets are full of people milling around, taking a beer here and there, calling out to acquaintances, as most flows of passage, here to there, are interrupted. Although the interruption can be a source of frustration, like the interruption of water or electricity, it becomes a necessity for everyone in that it provides a mechanism for people to switch gears, to consider other options, to take on needed information about what is happening in the neighborhood or city. [...] These urbanized provocations and openings may not be sufficient to change the critical economic infrastructure of cities, but they do, nevertheless constitute a platform to explore the elements of what might be called an anticipatory urban politics more capable of mitigating exploitation.

(pp. 125-126)

This 'politics of anticipation' is about people on their toes, working at the crossroads, connecting differences to create possibilities to eke out a livelihood and scale their existences to access the city. This is an intimate sociology of difference where people are infrastructure, calling forward a different way of doing politics, which is still to be fully grasped and understood. While the analytics of collective action developed in EuroAmerican cities were based on structuralist or constructionist notions of class, identity and mobilization of (preknown) resources (e.g. CASTElls, 1983; BenfORd and SNOW, 2000; DiAni and MCADAm, 2003), these categories seems less valid here, or more difficult to use in thinking about platforms of engagement. Rather than a 'social movement', this is 'a movement at the crossroads', characterized by uncertain outcomes, which asks analysts also to be less sure of themselves in pushing their analytical building blocks onto the world. The grand collective projects that were theorized and aimed towards public contestation over resource distribution are replaced by a less collectivized, but still collective, politics of anticipation, also challenging how the politics and mechanisms of broader-scale change can be theorized.
Pieterse's City Futures (2008) provides a more explicit attempt to move across scales to understand the possibility of change. If Simone is feverishly searching and testing how to connect words with worlds, Pieterse is more analytical - while recognizing and pushing for rich descriptions. He calls his approach of understanding action across scales 'radical incrementalism' or the 'relational city'. It works through various kinds of engagements between the state, civil society and the private sector, describing the actors involved and strategies deployed. Instead of suggesting which of these are more or less appropriate forms of engagement, he highlights the need for transgression in all forms of engagement. He explores the related concepts of 'quiet encroachment' (BAYAT, 2000; SCOTT, 1985), as well as the example of more organized and explicit intervention through the case of Slum Dwellers International (SDI). He claims that the significance of the SDI approach 'is not pitting the solution proposed by the poor against the state programme, or lobbying directly for policy change, but rather the seeking of "shifts" in the institutional arrangements which determine the way policy translates into action' (PIETERSE, 2008, p. 116). The emphasis lies in finding intermediaries and strategic ways so as to shift institutions slowly, progressively to become sensitized and work for the marginalized.

One key way through which to develop these kinds of strategies is through the formation of 'epistemic communities' - or strategic networks. Their purpose is to challenge 'conventional orthodoxy (the mainstream) of what is possible and not possible', forging new ideas based on practical judgement 'in the moment of action'? Importantly, these epistemic communities and the relational engagement that they engender between state, civil society and the private sector are not seen as consensus-building arenas. Instead, the 'perverse persistence of brutal inequality in cities of the South requires a politics of transgression that valorizes agonistic engagement' (p. 106).

The conceptual vector of platforms of engagement is thus articulated around the drive to understand how African urban subjectivities are formed in relation to urban inequality and crisis. It emphasizes the rigorous task of building a descriptive body of academic 'knowing' of everyday African cityness, arguing that this is how insights can be gained into what transformative junctures or leverage points for intervention could exist.

\section{CONCLUSION}

The motivation for conceptual vectors is based on RoY's (2009) notion that regional histories and contexts shape cities, and while scholarly debates and concepts are rooted in place, they may travel and inform theory elsewhere. Following from this, this paper has argued 
that the strategic essentialism of the 'African city' which emerges from scholarly attention to the features of crisis, colonialism, informalization and 'blackness' brings into view an emergent and important body of work that takes African cities seriously as locations for theory-making. This work is framed by two conceptual vectors, 'engaged theory-making' and 'platforms of engagement', that together provide a provisional meta-framework for further theory-making in the African context.

Although these conceptual vectors are not the only areas in which African urban research ought to be undertaken, the paper has pointed towards particular facets of African cities that will be useful to examine, as well as areas of strength in existing Africa urban scholarship, and provided a particular rationale and focus for more work in these areas. More research is needed to consolidate theoretical contributions and further the task of effectively challenging Northern theory. There is a clear need for further ethnographic urban work to test and work out whether and how these conceptual vectors make sense in diverse contexts and are useful in organizing academic work and the co-production of urban knowledge suitable for different African cities. Work on a wider range of cities is needed to test the utility of the strategic essentialism of considering 'African cities' to provide material for thinking across cities. For example, following SimONE's (2011b) notion of 'black urbanism', a network of Africanists could engage others working in Brazil and India facing similar processes of urbanization, which will most likely lead to further cross-breeding of theoretical attitudes.

Conceptual vectors should be taken as 'a way of formulating questions, concepts, practices of engagement, and methods of investigation' (SimONE, 2011b, p. 285). They provide a lens through which to think the city anew, while rooted in key features of African cities. With increasing academic attention to cities in the global South, this type of theoretical-methodological intervention for critical scholars is crucial in order to transcend established but ineffective analytical categories that always seem to operate with certainty, but without providing much possibility for change. These conceptual vectors can serve as intellectual devices to promote and focus debates and the organizing of research in the future. In conclusion, this paper briefly points towards possible research, debate and action that will contribute to the development of these vectors, enhancing their utility for broader theory-making.

It was argued that African academics are well placed to begin developing 'engaged theory-making'. Certainly there is international literature reflecting on transcending existing academic boundaries. However, African academics have a long history of developmentalist work, and therefore reflecting on this history provides a means for making a specific theoretical contribution with wider relevance. This conceptual vector also raises a set of important questions relating to the ethical and political project of research. In particular, there are risks associated with a mode of research production and theorizing characterized by engagement and collaboration with real communities, political actors and policy systems. The risks lie in reproducing the uncritical developmentalism and instrumentalism that has been criticized in recent literature on the urban South. How is it that academic researchers can engage but keep their own political intentions, or set of objectives intact? Put differently, how can they locate their engagements and theoretical reflections within a wider theory of political change, which is neither so immediate (as is seen with studies foregrounding the struggles of the poor and their claims to individual rights, for example) nor so totalizing (the idea that poor will never be uplifted unless the 'system' is transformed in its entirety) in its claims so as to be disabling to those working in the context of the academic institution?

The conceptual vector of 'platforms of engagement' can be of assistance in answering these questions. This vector sees processes of informalization, often viewed as a negative aspect of African cities, as a means of organizing entailing opportunities for radical incrementalism. The politics that become possible through this vector might be less clear-cut than in, for instance, neoMarxist approaches, but by insisting on using descriptive ethnographic registers, more aspects of urban life - and the knowledge-making surrounding it - can be politicized. Through studying 'platforms of engagement' one can arrive at a more fine-grained understanding of how the city and its unequal resource distribution is produced, and reinvigorate questions of how to democratize the making of cities, which is profoundly shaped by intertwined processes of formalization and informalization. However, in this regard there are still unanswered questions: how can one hold onto the modernist notion of improving life for the many, of being radical and progressive, when the platforms of engagement in both Simone (permutation of differences at the crossroads) and Pieterse (epistemic communities) appear so unstable? While the notion of 'radical incrementalism' suggests a slow 'hacking' of the system to open up possibilities that can be seized and exploited, and later institutionalized to shape wider processes (ERNSTSON, 2013), discussions are needed around how to understand what is 'radical' and what is 'incremental' in the evershifting terrain of action. How can one avoid the obvious risk that those more secure in the city with less turbulent lives - often the middle-class - will not take over the definitional practice of deciding objectives and course of action? Indeed, how can intermediary platforms between, for instance, slum-dwellers, activists, academics and civil servants be created that can sustain, and negotiate, what is to be taken as radical?

Dealing with these questions will begin to generate new ways to think the African city and urban scholarship. By strategically reflecting on diverse experiences 
across the continent, a new theory or organizing device can be crafted, which of course can be challenged and translated differently between locations. The two conceptual vectors discussed here are crafted to serve this purpose, and would themselves be enriched from it. In this spirit, this paper invites others to participate in discussions, research and action to work out the usefulness of these and other conceptual vectors in facing the challenges of urbanization in Africa, and beyond.

Acknowledgements - The authors are grateful to Susan Parnell, Edgar Pieterse, Gordon Pirie, Jennifer Robinson and Vanessa Watson for ideas, arguments and critical comments made on earlier drafts of this paper. The authors also thank several anonymous reviewers and Lizi Dawes and Gordon MacLeod at Regional Studies for constructive and engaging comments, which helped improve this paper. The authors also thank Gareth Haysom and Anna Taylor for their input in an early literature seminar.

Funding - This work was supported by the Swedish Research Council Formas which provided public funding through the research grant Ways of Knowing Urban Ecologies (WOK-UE) [grant number 250-2010-1372]. Together this made it possible to write this paper, but of course the authors remain responsible for its opinions and arguments.

\section{NOTES}

1. The 'African city' is a conceptual standpoint that we (and others, in particular Myers 2011; Pieterse and Simone 2013) find broad enough to gather diverse intellectual, artistic and activist interests and capabilities, and which can be used to critique established ways of thinking about cities and urbanization. As such this standpoint is a political strategy in the struggle over intellectual knowledge production and aims to cut out a space from which to think cities and city-making anew, based on experiences from Africa. Those gathering here might have their differences, and we might, and should, critique our theoretical standpoint, and ultimately we might abandon it all together when it is no longer deemed useful or strategic. See also Ferguson (2006) on the problems and necessities to speak into the cultural figure of 'Africa'. The term 'strategic essentialism' has been much discussed, in particular in relation to feminism (SPIVAK, 1989).

2. For Simone (2011c) this is a distinctively Deleuzian enterprise; Simone's essay provides a rare account of how his work draws upon broader theoretical debates.

3. Admittedly this differs from settler colonies such as South Africa (since 1652), to uncolonized Ethiopia and from 50 years of liberation in Ghana to Namibian independence in 1990.

4. Although the focus here is on the material manifestations of processes of informalization, authors such as Ananya
Roy (Roy, 2005, 2011) have demanded that the theoretical discourse of informality be extended beyond the consideration of the substantive nature of various extralegal activities occurring within the physical space of cities, and associated exclusively with the urban poor. RoY (2005) posits that informalization is better understood as a mode of production of space fundamentally determined by the procedures and instruments of state planning. Planning is implicated in the production of informality as a facet of a 'state of exception', enabling some degree of 'territorial flexibility' through which 'the valorization of elite informalities and the criminalization of subaltern informalities produce an uneven urban geography of spatial value' (Roy 2011, p. 233). The effects of this territorial flexibility, and the creation of 'zones of exception', wherein conventional human and legal rights of residents can be suspended or relaxed, are acutely felt in African cities, where an anti-urban political bias often joins forces with official planning and legal instruments to motivate evictions and demolitions (KAmete, 2013). The 'informal' should thus be viewed as part and parcel of city-making, used by state, capital and residents as a way to create value and use the city through legal and illegal activities (ROY, 2005, 2011; cf. Fourchard, 2011, on Lagos; cf. Murray, 2011, on Johannesburg).

5. This view is inspired by comparative urbanists, but also by Annmarie Mol's attempt to think differently about theory in her discussion about actor-network theory, where theory-making becomes less about 'crafting an overall scheme' but to develop a 'set of sensitivities [that] helps to tell cases, draw contrasts, articulate silent layers $[\ldots]$ and shift stories from one context to another' (MoL, 2010, p. 253).

6. The accomplishment of building, funding and organizing the ACC has been developed by particular persons at great cost in terms of time and effort and a lifetime of commitment, including, in particular, Vanessa Watson, Susan Parnell and Edgar Pieterse. A detailed history by those involved would be of great value. Attention is drawn to the practices of South African urbanists because linking theory and practice has not been the special task of certain scholars or programmes, but instead an engrained way of doing academic scholarship. The tight connections between theory and practice among South African scholars during and after apartheid signals how such relations can articulate themselves into a very particular research centre.

7. In developing his notion of 'epistemic communities', Pieterse (2008, pp. 148-151) combines the ideas of 'organic intellectuals' - from Antonio Gramsci's and Edward Said's works - with the Aristotelian notion of 'phronesis' - the skill and reason of practical judgement in the moment of action - and how it has been reworked by planning theorist Bent Flyvbjerg (Flyvbjer G, 2004). There is also a resemblance to organizational sociologists Jean Lave and Etienne Wenger's work on situated learning and communities of practice (LAVE and WENGER, 1991).

\section{REFERENCES}

Amin A. (2004) Regulating economic globalization, Transactions of the Institute of British Geographers 29, 217-233.

Amin A. (2010) Remainders of race, Theory, Culture and Society 27, 1-23. 
Anderson P. M. L., Cartwright A., Brown-Luthango M., Farouk I. and Smit W. (2013) Brokering communities of knowledge and practice: reflections on the African Centre for Cities' CityLab Programme, Cities 32, 1-10.

BayAt A. (2000) From 'dangerous classes' to 'quiet rebels': politics of the urban subaltern in the global south, International Sociology 15, 533-557.

Benford R. D. and Snow D. A. (2000) Framing processes and social movements: an overview and assessment, Annual Review of Sociology 26, 611-639.

Besteman C. (2008) Transforming Cape Town. University of California Press, Berkeley, CA.

Bienefeld M. (1988) Dependency, theory and the political economy of Africa's crisis, African Studies Review 43, 68-87.

Castells M. (1983) The City and the Grassroots. Edward Arnold, London.

Chipkin I. (2005) The political stakes of academic research: perspectives on Johannesburg, African Studies Review 48, 87-109.

Comaroff J. and Comaroff J. (2011) Theory from the South: Or, How Euro-America is Evolving Toward Africa. Paradigm, Boulder, $\mathrm{CO}$.

Connell R. (2007) Southern Theory: The Global Dynamics of Knowledge in Social Science. Allen \& Unwin Australia, Sydney, NSW, and Polity, Cambridge.

Cooper F. (1983) Struggle for the City: Migrant Labor, Capital, and the State in Urban Africa. Sage, Beverly Hills, CA.

Coquery-Vidrovitch C. (2005) The History of African Cities South of the Sahara: From the Origins to Colonization. Markus Wiener, Princeton, NJ.

Davis M. (2006) Planet of Slums. Verso, London.

De Bоеск F. (2010) Cemetery State [Video Documentary]. FilmNatie.

De Boeck F. and Plissart M. (2005) Kinshasa: Tales of the Invisible City. Ludion, Ghent.

Diani M. and McAdam D. (Eds) (2003) Social Movements and Networks: Relational Approaches to Collective Action. Oxford University Press, Oxford.

Diouf M. (2003) Engaging postcolonial cultures: African youth and public space, African Studies Review 46, 1-12.

Duminy J. (2013) Workshop Proceedings: African Urban Research Initiative. Report after the Conference 'African Urban Research Initiative', Addis Ababa, Ethiopia, 20-21 March 2013. African Centre for Cities, University of Cape Town, Cape Town.

Edjabe N. and Pieterse E. (Eds) (2010) African Cities Reader: Pan-African Practices. Chimurenga Press \& African Centre for Cities, Cape Town.

Edjabe N. and Pieterse E. (Eds) (2011) African Cities Reader II: Mobilities \& Fixtures. Chimurenga Press \& African Centre for Cities, Cape Town.

ERNSTSON H. (2013) Re-translating nature in post-apartheid Cape Town: the material semiotics of people and plants at Bottom Road, in Heeks R. (Ed.) Actor-Network Theory for Development. Working Paper No. 4. University of Manchester, Manchester (available at: http://www.cdi.manchester.ac.uk/resources/ant4d/documents/ANT4DWorkingPaper4Ernstson.pdf).

Ferguson J. (1992) The country and the city on the Copperbelt, Cultural Anthropology 7, 80-92.

Ferguson J. (2006) Global Shadows: Africa in a Neoliberal World Order. Duke University Press, Durham, NC.

Flyvbjerg B. (2004) Phronetic planning research: theoretical and methodological reflections, Planning Theory and Practice 5, 283-306.

FourChard L. (2011) Lagos, Koolhaas and partisan politics in Nigeria, International Journal of Urban and Regional Research 35, $40-56$.

Freund B. (2007) The African City: A History. Cambridge University Press, New York, NY.

GANDy M. (2006) Planning, anti-planning and the infrastructure crisis facing metropolitan Lagos, Urban Studies 43, 371-396.

Goebel A., Hill T., Fincham R. and Lawhon M. (2010) Transdisciplinarity in urban South Africa, Futures 42, 475-483.

Grosz E. and Spivak G. C. (1985) Criticism, feminism and the institution. An interview with Gayatri Chakravorty Spivak, Thesis Eleven 10-11, 175-189.

Guyer J. I. (2011) Describing urban 'no man's land' in Africa, Africa 81, 474-492.

HARrison P. (2006) On the edge of reason: planning and urban futures in Africa, Urban Studies 43, 319-335.

Heynen N. C., Kaika M. and Swyngedouw E. (Eds) (2006) In the Nature of Cities: Urban Political Ecology and the Politics of Urban Metabolism. Routledge, London.

IMRIE R. (2004) Urban geography, relevance, and resistance to the 'policy turn', Urban Geography 25, 697-708.

Kamete A. Y. (2013) Missing the point? Urban planning and the normalisation of 'pathological' spaces in southern Africa, Transactions of the Institute of British Geographers 38, 639-651.

KING A. (1990) Urbanism, Colonialism and the World Economy: Cultural and Spatial Foundations of the World Urban System. Routledge, London.

Lave J. and Wenger E. (1991) Situated Learning: Legitimate Peripheral Participation. Cambridge University Press, New York, NY.

Lawhon M., Patel Z. and Taylor A. (2012) Co-Producing Knowledge on Urban Sustainability Through Local Government-University Interactions: A Case Study of Mistra Urban Futures in Cape Town. State of African Cities and ICLEI/UN-Habitat, Cape Town.

Lawhon M., Ernstson H. and Silver J. D. (2014) Provincialising urban political ecology: towards a situated UPE through African urbanism, Antipode 46, 497-516. DOI: 10.1111/anti.12051.

Lindell I. (Ed.) (2010) Africa's Informal Workers: Collective Agency, Alliances and Transnational Organizing in Urban Africa. Zed, London.

Locatelli F. and Nugent P. (2009) African Cities: Competing Claims for Urban Spaces. Brill, Leiden.

Lourenco-Lindell I. (2004) Trade and the politics of informalisation in Bissau, Guinea-Bissau, in Tranberg Hansen K. and VaA M. (Eds) Reconsidering Informality: Perspectives from Urban Africa, pp. 84-98. Nordic Africa Institute, Uppsala.

Mabin A. (1990) Limits of urban transition models in understanding South African urbanisation, Development Southern Africa 7, 311-322. 
Mabogunje A. L. (1990) Urban planning and the post-colonial state in Africa: a research overview, African Studies Review 33, 121-203.

Massey D. (2005) For Space. Sage, London.

Mbembe A. (1992) Provisional notes on the postcolony, Africa, Journal of the International African Institute 62, 3-37.

Mbembe A. (2002) African modes of self-writing, Public Culture 14, 239-273.

Mbembe A. and Nuttall S. (2004) Writing the world from an African metropolis, Public Culture 16, 347-372.

Mbembe A. and Roitman J. (1995) Figures of the subject in times of crisis, Public Culture 7, 323-352.

McDonald D. (2008) World City Syndrome: Neoliberalism and Inequality in Cape Town. Routledge, New York, NY.

Mobjork M. (2010) Consulting versus participatory transdisciplinarity: a refined classification of transdisciplinary research, Futures 42, 866-873.

Mol A. (2010) Actor-network theory: sensitive terms and enduring tensions, Köllner Zeitschrift für Soziologie und Sozialpshychologie 50, 253-269.

Murdoch J. (2006) Post-Structuralist Geography. Sage, London.

Murray M. (2011) City of Extremes: The Spatial Politics of Johannesburg. Wits University Press, Johannesburg.

Murray M. J. and Myers G. (Eds) (2006) Cities in Contemporary Africa. Palgrave MacMillan, New York, NY.

Myers G. (2011) African Cities: Alternative Visions of Urban Theory and Practice. Zed, London.

Nuttall S. and Mbembe A. (2005) A blasé attitude? A response to Michael Watts, Public Culture 17, 193-201.

Nuttall S. and Mbembe A. (Eds) (2008) Johannesburg: The Elusive Metropolis. Wits University Press, Johannesburg.

Oldfield S., Parnell S. and Mabin A. (2004) Engagement and reconstruction in critical research: negotiating urban practice, policy and theory in South Africa, Social and Cultural Geography 5, 285-299.

O’Toole S., Pieterse E. and Tavengwa T. (Eds) (2012) CityScapes. Biannual magazine published by Tau Tavengwa \& African Centre for Cities, University of Cape Town, Cape Town (available at: http://africancentreforcities.net/publications/10/).

Parnell S. (1997) South African cities: perspectives from the ivory towers of urban studies, Urban Studies 34, 891-906.

PARNELl S. (2007) The academic-policy interface in post-Apartheid urban research: personal reflections, South African Geographical Journal 89, 111-120.

PARnell S. and Robinson J. (2012) (Re)theorizing cities from the Global South: looking beyond neoliberalism, Urban Geography 33, 593-617.

Parnell S., Pieterse E. and Watson V. (2009) Planning for cities in the global South: an African research agenda for sustainable human settlements, Progress in Planning 72, 233-241.

Patel Z. (2006) Africa: a continent of hope?, Local Environment 11, 7-15.

Pieterse E. (2008) City Futures: Confronting the Crisis of Urban Development. Zed, London.

Pieterse E. (2010a) Cityness and African urban development, Urban Forum 21, 205-219.

Pieterse E. (Ed.) (2010b) Counter-currents: Experiments in Sustainability in the Cape Town Region. Jacana, Johannesburg.

Pieterse E. (2011) City studies in (South) Africa: here and now. Paper presented at the South African City Studies Conference II, University of Cape Town, Cape Town, South Africa, 7 September 2011.

Pieterse E. and Simone A. (Eds) (2013) Rogue Urbanism: Emergent African Cities. Jacana, Johannesburg.

Potтs D. (2010) Circular Migration in Zimbabwe and Contemporary Southern Africa. James Currey, Woodbridge.

Robinson J. (2002) Global and world cities: a view from off the map, International Journal of Urban and Regional Research 26, 531-554.

Robinson J. (2006) Ordinary Cities: Between Modernity and Development. Routledge, London.

Robinson J. (2011) Cities in a world of cities: the comparative gesture, International Journal of Urban and Regional Research 35, 1-23.

Robinson J. (2013) The urban now: theorizing cities beyond the new, European Journal of Cultural Studies 16, 659-677. DOI:10. $1177 / 1367549413497696$.

Rogerson C. and Robinson J. (1999) South Africa: different geographies, Geoforum 30, v-vi.

Roy A. (2005) Urban informality: toward an epistemology of planning, Journal of the American Planning Association 71, $147-158$.

Roy A. (2009) The 21st-century metropolis: new geographies of theory, Regional Studies 43, 819-830.

Roy A. (2011) Slumdog cities: rethinking subaltern urbanism, International Journal of Urban and Regional Research 35, $223-238$.

Scotт J. (1985) Weapons of the Weak: Everyday Forms of Peasant Resistance. Yale University Press, New Haven, CT.

SeEkings J. and KeIL R. (2009) The International Journal of Urban and Regional Research: an editorial statement, International Journal of Urban and Regional Research 33, $\mathrm{i}-\mathrm{x}$.

Sheppard E., Leitner H. and Maringanti A. (2013) Urban pulse - provincializing global urbanism: a manifesto, Urban Geography 34, 893-900.

Simmel G. (1997) The metropolis and mental life [1903], in Frisby D. and Featherstone M. (Eds), Simmel on Culture. Sage, London.

Simon D. (1992) Cities, Capital and Development: African Cities in the World Economy. Belhaven, London.

Simone A. (2001) On the worlding of African cities, African Studies Review 44, 15-41.

Simone A. (2004a) People as infrastructure: intersecting fragments in Johannesburg, Public Culture 16, 407-429.

Simone A. (2004b) For the City Yet to Come. Duke University Press, Durham, NC.

Simone A. (2011a) The ambivalence of the arbitrary: a supplement to Ash Amin's 'The remainders of race', Theory, Culture and Society 28, 129-137.

Simone A. (2011b) City Life from Jakarta to Dakar: Movements at the Crossroads. Routledge, London.

Simone A. (2011c) The surfacing of urban life: a response to Colin McFarlane and Neil Brenner, David Madden and David Wachsmuth, City 15, 355-364.

Simone A. and Abouhani A. (Eds) (2005) Urban Africa: Changing Contours of Survival in the City. CODESRIA, Dakar. 
Skinner C. (2008) Street Trade in Africa: A Review. WIEGO Working Paper No. 5. Women in Informal Employment: Globalizing and Organizing (WIEGO) (available at: http://wiego.org/sites/wiego.org/files/publications/files/SKINNER_WIEGO_ WP5.pdf) (accessed on 10 December 2012).

Spivak G. C. (1989) In a word: interview, Differences 1, 124-156.

Stren R. E. (1992) African urban research since the late 1980s: responses to poverty and urban growth, Urban Studies 29, $533-555$.

STREN R. E. (1994) Urban research in Africa, 1960-92, Urban Studies 31, 729-743.

UN-Habitat (2010) The State of African Cities 2010: Governance, Inequality and Urban Land Markets. UN-Habitat, Nairobi.

Van Donk M., Pieterse E., Swilling M. and Parnell S. (Eds) (2008) Consolidating Developmental Local Government: Lessons from the South African Experience. University of Cape Town Press, Cape Town.

Vengroff R. (1977) Dependency, development, and inequality in Black Africa, African Studies Review 20, 17-26.

W ANYOIKE J. (2013) Incorporating informal markets into Nairobi's urban realm, Newsletter (Centre for Urban Innovation, University of Nairobi) (available at: http://www.centreforurbaninnovations.com/content/incorporating-informal-markets-nairobi's-urbanrealm) (accessed on 11 November 2013).

Watson V. (2002) The usefulness of normative planning theories in the context of Sub-Saharan Africa, Planning Theory 1, $27-52$.

Watson V. (2003) Conflicting rationalities: implications for theory and ethics, Planning Theory and Practice 4, $395-407$.

Watts M. (2005) Baudelaire over Berea, Simmel over Sandton?, Public Culture 17, 181-192.

Wickson F., CARew A. L. and Russel A. W. (2006) Transdisciplinary research: characteristics, quandaries and quality, Futures $\mathbf{3 8}$, 1046-1059. 